\title{
Effects of season and sex on voluntary dry matter intake, digestibility and performance of the Fiji Fantastic sheep fed native guinea grass (Panicum maximum) diet
}

\author{
E.M. Aregheore ${ }^{1}$ and I. Rokomatu \\ The University of the South Pacific, \\ School of Agriculture, Animal Science Department \\ Alafiua Campus, Apia, Samoa
}

(Received 17 December 2003; revised version 28 June 2004; accepted 25 August 2004)

\begin{abstract}
Effects of season and sex on voluntary dry matter intake (DMI), growth, digestibility and performance of the Fiji Fantastic sheep fed native guinea grass (Panicum maximum) was investigated. Twelve lambs (6 ram lambs and 6 ewe lambs) from the sheep-breeding unit, Nawaicoba (Fiji) were selected and used in the two seasonal phase trials. Six lambs each ( $3 \mathrm{ram}$ and 3 ewe), with pre-trial liveweight and age $25.1 \pm 1.15 \mathrm{~kg}$ and $5-6$ months, and $20.0 \pm 0.00 \mathrm{~kg}$ and 4-5 months of age were used in dry and wet seasons (trials 1 and 2), respectively. The lambs in each trial were selected as closely as possible for liveweight. The experimental design was a completely randomized $2 \times 2$ factorial [ $(2$ seasons (dry and wet) $\times 2$ sexes (females and males)]. Trial 1 was from October $3^{\text {rd }} 2002-28^{\text {th }}$ January 2003 (92 days), while trial 2 was from February $12^{\text {th }}-8^{\text {th }}$ May 2003 (84 days). Seasons had effects on chemical composition of the forage. Except for crude protein (CP), dry matter (DM), neutral detergent fibre (NDF), acid detergent fibre (ADF), hemicellulose, cellulose and energy (MJ/kg, DM), were higher in the dry (D) than in the wet season (W). DMI of sheep was $536 \pm 0.50$ and $792 \pm 7.51 \mathrm{~g} /$ head/d in D and $\mathrm{W}$ seasons, respectively. Season but not sex had significant $(\mathrm{P}<0.001)$ effect on DMI. ADG was $34.5 \pm 2.5$ and $35.5 \pm 3.5 \mathrm{~g} / \mathrm{head} / \mathrm{d}$ and season and sex had no significant ( $P>0.001$ ) effects on ADG. Feed efficiency ( $\mathrm{kg} \mathrm{DMl} / \mathrm{kg}$ liveweight gain) was $15.6 \pm 1.1$ and $22.5 \pm 2.0$ in $\mathrm{D}$ and $\mathrm{W}$ seasons, respectively. Water intake (WI) in D and W seasons was $1328.8 \pm 9.9$ and $550.2 \pm 9.8 \mathrm{~L}$, respectively. Season and DMI had significant $(P<0.001)$ effect on WI. Blood urea-N and blood glucose concentrations at the pre-and post-experimental periods were similar and sex had no effect on their concentrations. Season but not sex had effect on apparent digestibility of CP, NDF, hemicellulose and energy. Also, season had significant effect $(\mathrm{P}<0.001)$ on
\end{abstract}

${ }^{1}$ Corresponding author: e-mail: aregheore_samoa.usp.ac.fj 
nutritive value index (NVI) of guinea grass. Daily CP intake (DCPI) was $3.6 \pm 0.10$ and $9.4 \pm 0.05$ $\mathrm{g} / \mathrm{kgW}^{0.75} / \mathrm{d}$ in D and W seasons, respectively. Our data confirmed that native guinea grass in the unit would not adequately support the growth of lambs in the $\mathrm{D}$ and $\mathrm{W}$ seasons because of its poor nutritive quality. In conclusion, supplementation is recommended to improve liveweight gain and general performance of the Fiji Fantastic sheep on sole diet of native guinea grass in the $\mathrm{D}$ and $\mathrm{W}$ seasons.

KEY WORDS: season, guinea grass, Fiji Fantastic sheep, chemical composition, DMI, ADG, digestibility

\section{INTRODUCTION}

The grazing of available native pasture that is nutritionally limited due to environmental/or climatic conditions largely supports sheep production in Fiji. In the wet season, there is enough pasture for sheep to graze, but this may not be the case during the dry season. In the dry season, the nutritional quality of most forages including guinea grass declines resulting in low utilization due to high cell contents, low availability of carbohydrate and nitrogen. Precise comparisons are few in the tropics, however observations indicate that gain and efficiency of feed conversion are reduced during the dry season due to unavailability of good quality forage for grazing animals.

Guinea grass (Panicum maximum) is second to batiki grass (Ischaemum aristatum var. indicum) in Fiji, in terms of availability. In areas where batiki grass is scant it dominates the natural pasture and most farmers rely in it for the supply of nutrients for their grazing sheep in both dry and wet seasons. Scant literature is available in the Pacific Island countries (PICs) on the chemical composition and nutritive value of most pasture species. Also information on effects of season on nutrient quality and utilization of pasture species in the PICs is scant.

The Fiji Fantastic (FF) sheep, a crossbred (Wiltshire $\times$ Blackbelly Barbados) is well adapted to the climatic conditions of Fiji. It has good performance characteristics and amongst these it sheds its wool naturally and this is an advantage to its survival in the hot and humid weather of Fiji (Manueli, 1997). There is no information on the Fiji Fantastic sheep with respect to feed intake and utilization when grazed on native guinea grass or when it is fed in stalls using the cut-and-carry system. The objective of this investigation therefore was to report on the voluntary dry matter intake, digestibility and performance of the Fiji Fantastic sheep fed native guinea grass (Panicum maximum) in the dry and wet seasons at Nawaicaoba (Fiji). 


\section{MATERIAL AND METHODS}

\section{Animals, experimental design and management}

Two seasonal phase trials were conducted at the sheep-breeding unit, Nawaicoba (Fiji). Trial 1 was carried out during the dry season over a period of 92 days ( $3^{\text {rd }}$ October $2002-28^{\text {th }}$ January 2003) and the climatic condition was mean temperature, $30.7^{\circ} \mathrm{C}$; mean rainfall, $114.9 \mathrm{~mm}$ and relative humidity, approximately $70.3 \%$. Trial 2 in the wet season lasted for 84 days $\left(12^{\text {th }}\right.$ February $-8^{\text {th }}$ May 2003) with the following climatic condition, mean temperature, $31.5^{\circ} \mathrm{C}$; mean rainfall, $421.1 \mathrm{~mm}$, and a relative humidity of approximately $73.8 \%$.

Twelve lambs ( 6 ram lambs and 6 ewe lambs) were selected for the trials. In trial 1 (dry season) six lambs ( 3 ram lambs and 3 ewe lambs) with pre-trial liveweight of $25.1 \pm 1.15 \mathrm{~kg}$ and between 5-6 months of age were selected and used. In trial 2 (wet season) the same number of lambs ( 3 ram lambs and 3 ewe lambs) with pre-trial liveweight of $20.0 \pm 0.00 \mathrm{~kg}$ and between $4-5$ months of age were selected. Lambs were assigned in completely randomized $2 \times 2$ factorial design [ $(2$ seasons (wet and dry) $\times 2$ sexes (females and males) $)$. Equal numbers of both sexes ( 3 females and 3 males) were assigned for each season.

The lambs were housed in individual pens under a common roof. Prior to the start of the trials, all lambs were de-wormed with Fenbendazole and allowed 15 days adjustment period to get used to their pens and feeding regimes. The lambs were fed only native guinea grass (Panicum maximum). However, they had free access to mineral lick blocks and water. The guinea grass was harvested from the same paddock on a daily basis and chopped with an electric chaff-cutter (Nagan Engineering, Fiji Limited, Ba, Fiji) to $9-10 \mathrm{~mm}$ pieces. The forage was given on an ad libitum basis three to four times daily to ensure constant availability and allow about $10-20 \%$ refusals.

The forage was sampled once a week for dry matter determination. Forage offered and refusals were recorded on a daily basis to estimate voluntary dry matter intake. In each trial only average weights at the beginning and end of the experiment were used to express liveweight change.

Blood samples were collected from the lambs at the beginning and last days (pre- and post-experimental periods) by jugular vein puncture into bijou bottles. The blood was allowed to clot at room temperature for approximately $15 \mathrm{~min}$ and then placed on ice and later centrifuged for $10 \mathrm{~min}$ at $1500 \mathrm{~g}$ to separate the serum and plasma, and stored at $-80^{\circ} \mathrm{C}$ until required for analysis. The samples were analysed for blood urea- $\mathrm{N}$ and glucose. 
Digestibility studies

At the end of trials 1 and 2, digestibility studies were carried out using all lambs. Ram lambs were fitted with harness bags. The ewes were housed in pens that has slatted floor covered with fine wire mesh that allows only urine to pass through. The animals were allowed 5 days adjustment period to get use to the management routine. The total faecal collection method was used for all lambs for 7 days.

Total faecal output for each lamb in each trial was weighed and a $25 \%$ sample was removed for dry matter determination. Faeces collected over the period, were oven dried at $70^{\circ} \mathrm{C}$ for $36 \mathrm{~h}$. Daily samples of faeces, refusals and forage were bulked separately for each lamb and milled with a simple laboratory mill to pass through $1.77 \mathrm{~mm}$ sieve and stored until required for chemical analyses.

\section{Analytical procedures}

AOAC (1995) methods were used to determine chemical composition of forage, refusals and faecal samples for $\mathrm{N}$ and ash. Fibre fractions, NDF, ADF and ADL were determined using procedures of Van Soest et al. (1991). Cellulose and hemicellulose fractions were calculated from the content of NDF, ADF and ADL. Gross energy $(\mathrm{MJ} / \mathrm{kg})$ values of forage and faecal samples were determined by a bomb calorimeter (Adiabatic bomb, Parr Instrument Co., Moline, IL) using thermochemical benzoic acid as standard. All analyses were done in triplicate.

The methods of Fawcett and Scott (1960) were used to determine blood urea$\mathrm{N}$ (BUN) concentration in the serum, while plasma glucose concentration was estimated by a colorimetric assay based on the use of hexokinase and glucose6-phosphate dehydrogenase (G-6-PD), (Kunst et al., 1983). The nutritive value index (relative intake $\mathrm{x}$ percent energy digestibility) of the forage was according to the method of Crampton et al. (1960).

\section{Statistical analysis}

Data on voluntary dry matter intake, growth rate, feed efficiency, water intake, blood metabolites, apparent nutrient digestibility coefficients and other calculated parameters for both trials were analysed as a completely randomized design for $2 \times 2$ factorial using MINITAB statistical software (Minitab, 2000). Where significant differences occurred, the least significant difference (LSD) test was used for mean separation. Also, any significant differences between dry and wet seasons within treatments were subjected to a Student's $t$-test. 


\section{RESULTS AND DISCUSSION}

Mean chemical composition of guinea grass (Panicum maximum) in the dry and wet seasons is presented in Table 1. Seasons have effect on the chemical composition of the forage. Except for crude protein (CP), dry matter (DM), NDF, $\mathrm{ADF}$, hemicellulose, cellulose and energy $(\mathrm{MJ} / \mathrm{kg}, \mathrm{DM})$ were higher in the dry than in the wet season. $\mathrm{CP}$ concentration of the forage for the dry and wet seasons was similar to value reported in Fiji for dry or cool season (Ranacou, 1986) and wet season (MAFF, 1999). Seasonal variation in environment has influence on forage quality and this often alters leaf/stem ratio that affects chemical composition of forage (Buxton, 1996). The concentrations of DM, CP, NDF, ADF and ash of the guinea grass in both seasons are within the ranges found in tropical grasses by Gohl (1981) and Aumont et al. (1995). Also the gross energy content of the guinea grass was within values reported by Aregheore (2001), Phimphachanhvongsod and Ledin (2002), and Aregheore and Cawa (2000) for the dry and wet seasons, respectively.

TABLE 1

Mean chemical composition of guinea grass (Panicum maximum)

\begin{tabular}{lcc}
\hline \multirow{2}{*}{ Item } & \multicolumn{2}{c}{ Season } \\
\cline { 2 - 3 } & dry & wet \\
\hline Dry matter (DM) & 54.9 & 30.1 \\
Composition of DM, \% & & \\
ash & & \\
crude protein & 9.4 & 11.3 \\
neutral detergent fibre & 8.2 & 12.8 \\
acid detergent fibre & 69.5 & 37.5 \\
acid detergent lignin & 34.9 & 25.0 \\
hemicellulose & 12.0 & 8.4 \\
cellulose & 32.6 & 12.5 \\
organic matter & 22.9 & 16.6 \\
Gross energy, $\mathrm{MJ} / \mathrm{kg}^{-1}$ & 90.6 & 88.7 \\
\hline
\end{tabular}

The leaf/stem composition and protein concentration is higher in immature forage than in mature one. The decline in protein concentration with advancing maturity (dry season guinea grass) occurs both due to decreases in protein leaves and stems, and because stems with their lower protein content, make up a larger portion of the herbage in more mature forage (Buxton, 1996). CP concentration of the forage in the dry season was lower than $11-12 \%$ suggested by NRC (1985) as adequate to meet requirements of growing sheep, however, it was not below $8.2 \%$ at which it could be considered as deficient. The wet season guinea grass was a 
regrowth of that harvested during the dry season period and therefore has high leaf/ stem composition that influenced the high CP concentration.

Data on performance characteristics of lambs in both seasons are presented in Table 2. Dry matter intake (DMI) of lambs was $536 \pm 0.50$ and $792 \pm 7.51 \mathrm{~g} / \mathrm{head} / \mathrm{d}$,

TABLE 2

Dry matter intake and performance characteristics of sheep on guinea grass during the dry and wet seasons

\begin{tabular}{lcc}
\hline \multirow{2}{*}{ Parameters } & \multicolumn{2}{c}{ Season } \\
\cline { 2 - 3 } & dry & wet \\
\hline Dry matter (DM) intake, $\mathrm{g} / \mathrm{d}$ & & \\
ram & 536 & 799 \\
ewe & 535 & 784 \\
mean & $536 \pm 0.50$ & $792 \pm 7.51$ \\
DM intake, $\mathrm{g} / \mathrm{kgW}^{0.75} / \mathrm{d}$ & & \\
ram & 42.2 & 75.3 \\
ewe & 44.7 & 75.4 \\
mean & $43.5 \pm 1.25^{\mathrm{a}}$ & $75.4 \pm 0.05^{\mathrm{b}}$
\end{tabular}

Feed efficiency, $\mathrm{kg} \mathrm{DMI} / \mathrm{kg}$ liveweight gain

$\begin{array}{lcc}\text { ram } & 14.5 & 20.5 \\ \text { ewe } & 16.7 & 24.5 \\ \text { mean } & 15.6 \pm 1.1^{\text {a }} & 22.5 \pm 2.0^{\text {b }}\end{array}$

Water intake, $\mathrm{L}$

ram 1338.6

ewe $\quad 1318.9$

540.4

mean

$1328.8 \pm 9.9^{\mathrm{a}}$

560.0

Experimental days

92

$550.2 \pm 9.8^{\mathrm{b}}$

Initial body weight, $\mathrm{kg}$

ram

26.2

20.0

ewe

23.9

20.0

mean

$25.1 \pm 1.15$

$20.0 \pm 0.00$

Final body weight, $\mathrm{kg}$

ram

29.6

23.3

ewe

26.8

22.7

mean

$28.2 \pm 1.40$

$23.0 \pm 0.30$

Average daily gain, $\mathrm{g}$

ram

ewe

mean

$34.5 \pm 2.5$

$35.5 \pm 3.5$

${ }^{a, b}$ means within row with different superscript differ at $\mathrm{P}<0.001$

\pm SD 
respectively, and when expressed on a metabolic weight basis as $\mathrm{g} / \mathrm{kgW}^{0.75} / \mathrm{d}$, DMI was $43.5 \pm 1.25$ and $75.4 \pm 0.05$ in dry and wet seasons, respectively. DMI was comparatively higher in the wet than in the dry season and the stage of growth of the forage may be implicated for the differences observed in DMI in both seasons. DMI is a reflection of the rate of passage and digestibility. The more digestible the pasture herbage the more animals will consume. However, DMI by lambs was not seriously affected in both seasons despite the comparative low DM content of the guinea grass and our results is in agreement with Gihad (1976).

Also the CP content in the dry season may be implicated in limiting intake of the native guinea grass. Intake of grass species declines rapidly when $\mathrm{CP}$ content of consumed forage fall below 7\% (Milford and Minson, 1966). CP content of the forage in the dry season period was above this level and with the ad libitum feeding regime it was envisaged that $\mathrm{CP}$ content in the native guinea grass eaten would be higher.

Mean average daily gain (ADG) of lambs in the dry and wet seasons was $34.5 \pm 2.5$ and $35.5 \pm 3.5 \mathrm{~kg} / \mathrm{head} / \mathrm{d}$, respectively. Although there was slight numerical difference between males and females in ADG (Table 2), season and sex had no significant $(\mathrm{P}>0.001)$ effect on $\mathrm{ADG}$ of the lambs. The low ADG suggested that the native guinea grass could not fully support high growth rate of lambs in both seasons. This observation is in agreement with Norton and Ash (1985) who reported low growth rate of goats grazing in Australia particularly in the post-weaning period, despite apparently adequate pasture in both quantity and quality.

The low ADG of lambs in both seasons may be due to the inability of rumen microorganisms to effectively utilize the influx of available $\mathrm{N}$ from the forage and this resulted in negative $\mathrm{N}$ utilization and subsequently low ADG. Generally, the deposition of protein depends on the efficiency of the use of absorbed protein, which is dependent on the availability of non-protein energy-yielding substrates and limiting essential amino acids (Poppi and McLennan, 1995). Feed efficiency ( $\mathrm{kg} \mathrm{DMl} / \mathrm{kg}$ liveweight gain) of lambs in the dry and wet seasons was $15.6 \pm 1.1$ and $22.5 \pm 2.0$, respectively, and they followed the pattern of DMI.

Water intake (WI) of lambs in the dry and wet seasons was $1328.8 \pm 9.9$ and $550.2 \pm 9.8 \mathrm{~L}$, respectively. Expressed on metabolic weight basis $\mathrm{Wl}$ of lambs in the dry and wet seasons averaged 108.6 and $52.4 \mathrm{~g} / \mathrm{kgW}^{0.75} / \mathrm{d}$, respectively. WI of the lambs was affected by season and amount of DMI of the forage. The moisture content of the forage was higher in the wet than in the dry season and this contributed to the differences in WI. Water intake is the sum of water consumed voluntarily by drinking and water contained in the feeds. Giger-Reverdin and Gihad (1991) reported that water intake is strongly influenced by the water content of the feeds. Our data on WI of lambs on guinea grass in both seasons supported the report of Giger-Reverdin and Gihad (1991) that DMI and water intakes are highly correlated. 
Table 3 presents the concentration of blood metabolites of lambs in the dry and wet seasons. Blood urea-N concentration was similar at the beginning and at the end of the trial (pre- and post-experimental periods) and sex had no effect. Tropical grasses decline rapidly in protein content resulting in reduced feed intake and digestibility, low rumen ammonia and blood urea levels (Adegbola et al., 1987). The differences in blood urea-N between our data and Adegbola et al. (1987) may be due to differences in breed and diets. Overall, BUN values for both seasons are within the ovine reference range (Hallford and Galyean, 1982).

TABLE 3

Concentration of blood metabolites during pre- and post-experimental periods for dry and wet seasons

\begin{tabular}{|c|c|c|}
\hline \multirow{2}{*}{ Indices } & \multicolumn{2}{|c|}{ Season } \\
\hline & dry & wet \\
\hline \multicolumn{3}{|c|}{$\begin{array}{l}\text { Blood urea-N (BUN), mmol/l } \\
\text { pre-experimental }^{1}\end{array}$} \\
\hline ram & 6.23 & 4.30 \\
\hline ewe & 4.57 & 4.80 \\
\hline mean & $5.4 \pm 0.83$ & $4.6 \pm 0.25$ \\
\hline \multicolumn{3}{|c|}{ post-experimental $^{2}$} \\
\hline ram & 6.57 & 5.47 \\
\hline ewe & 5.40 & 4.63 \\
\hline mean & $5.9 \pm 0.59$ & $5.0 \pm 0.42$ \\
\hline \multicolumn{3}{|c|}{$\begin{array}{l}\text { Blood glucose, } \mathrm{mmol} / \mathrm{l} \\
\text { pre-experimental }^{1}\end{array}$} \\
\hline ram & 3.43 & 2.50 \\
\hline ewe & 3.17 & 2.40 \\
\hline mean & $3.3 \pm 0.13$ & $2.5 \pm 0.05$ \\
\hline \multicolumn{3}{|c|}{ post-experimental $^{2}$} \\
\hline ram & 3.83 & 2.83 \\
\hline ewe & 3.60 & 2.93 \\
\hline mean & $3.7 \pm 0.12$ & $2.9 \pm 0.05$ \\
\hline
\end{tabular}

${ }^{1}$ beginning and ${ }^{2}$ end of the trial

Blood glucose concentration was also similar at the pre- and post-experimental periods. Season and sex had no major effect on blood glucose concentration of the lambs (Table 3). However, blood glucose was slightly higher in the dry than in the wet season. Generally, amount of DMI, energy and protein contents have influence on the concentration of blood glucose (Wright et al., 1962), but this was not the situation in this trial. 
Table 4 presents apparent nutrient digestibility coefficients of lambs in the dry and wet seasons. Season but not sex had effects on the apparent digestibility of CP, NDF, hemicellulose and energy of guinea grass by the lambs. The digestibility of feed decreases as intake increases (Galyean et al., 1990), due to faster passage rate through the alimentary tract (Loredo and Minson, 1973),

Apparent nutrient digestibility coefficients, $\%$

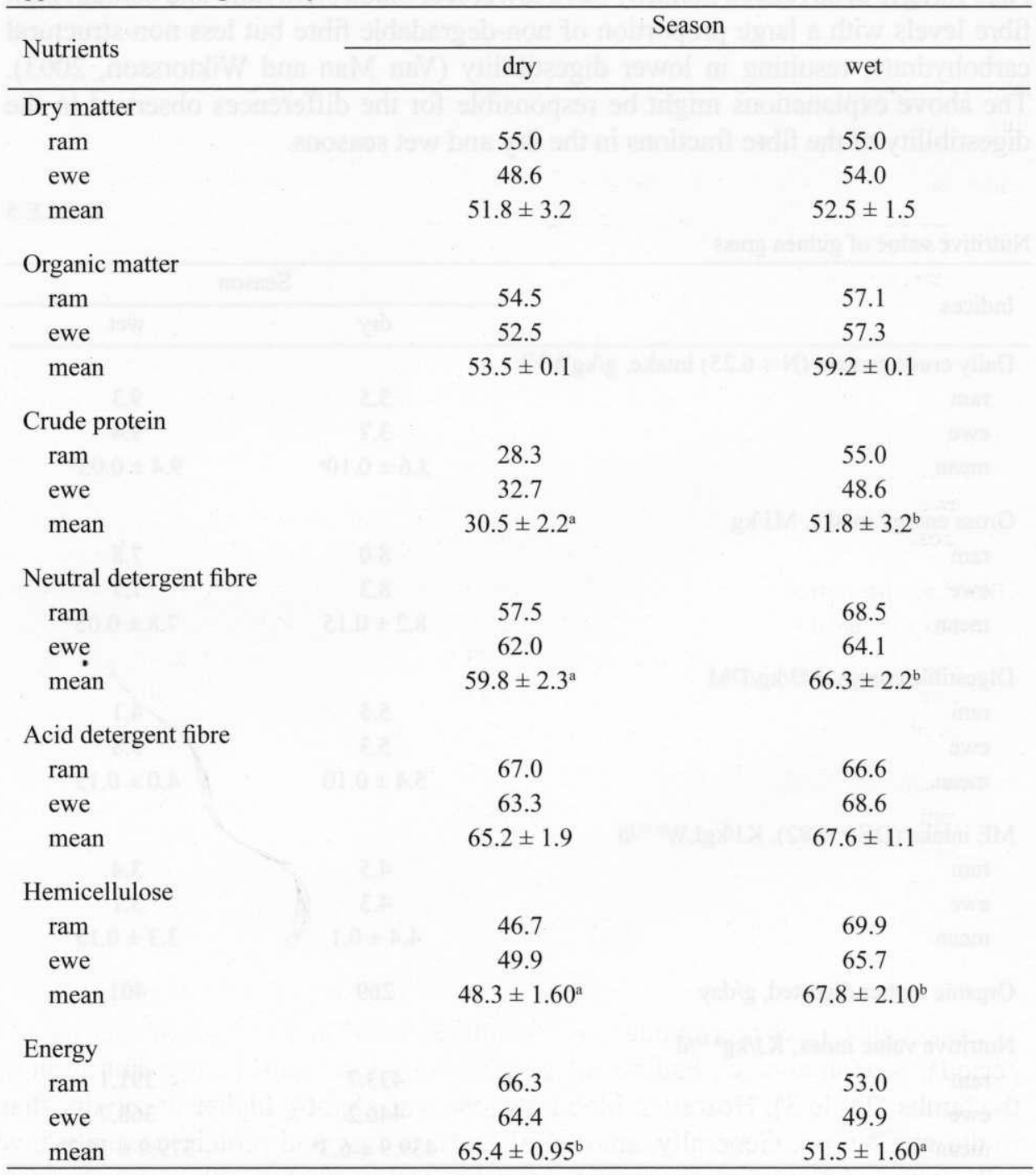

${ }^{\mathrm{a}, \mathrm{b}}$ means within row with different superscript differ at $\mathrm{P}<0.001$

$\pm \mathrm{SD}$ 
however, this was not the situation in our trial. Except for energy, the digestibility of DM, OM, CP, NDF, ADF and hemicellulose were higher for lambs in the wet season. DMI and CP content were higher in the wet season, while the fibre fractions and energy were higher in the dry.

In forage only diets $\mathrm{CP}$ is the main source of $\mathrm{N}$ for many species of rumen microorganisms and a low level of $\mathrm{N}$ intake as observed in the dry season native guinea grass might limit microbial growth resulting in low fermentative digestion. Also forages at advanced maturity have lower leaf blade/stem ratio and contain high fibre levels with a large proportion of non-degradable fibre but less non-structural carbohydrate, resulting in lower digestibility (Van Man and Wiktorsson, 2003). The above explanations might be responsible for the differences observed in the digestibility of the fibre fractions in the dry and wet seasons.

TABLE 5

Nutritive value of guinea grass

\begin{tabular}{|c|c|c|}
\hline \multirow{2}{*}{ Indices } & \multicolumn{2}{|c|}{ Season } \\
\hline & dry & wet \\
\hline \multicolumn{3}{|c|}{ Daily crude protein $(\mathrm{N} \times 6.25)$ intake, $\mathrm{g} / \mathrm{kgW}^{0.75}$} \\
\hline ram & 3.5 & 9.3 \\
\hline ewe & 3.7 & 9.4 \\
\hline mean & $3.6 \pm 0.10^{\mathrm{a}}$ & $9.4 \pm 0.05^{b}$ \\
\hline \multicolumn{3}{|l|}{ Gross energy intake, $\mathrm{MJ} / \mathrm{kg}$} \\
\hline ram & 8.0 & 7.8 \\
\hline ewe & 8.3 & 7.7 \\
\hline mean & $8.2 \pm 0.15$ & $7.8 \pm 0.05$ \\
\hline \multicolumn{3}{|l|}{ Digestible energy, $\mathrm{MJ} / \mathrm{kg} / \mathrm{DM}$} \\
\hline ram & 5.5 & 4.1 \\
\hline ewe & 5.3 & 3.8 \\
\hline mean & $5.4 \pm 0.10$ & $4.0 \pm 0.15$ \\
\hline \multicolumn{3}{|l|}{ ME intake $(\mathrm{DE} \times 0.82), \mathrm{KJ} / \mathrm{kgLW}^{0.75} / \mathrm{d}$} \\
\hline ram & 4.5 & 3.4 \\
\hline ewe & 4.3 & 3.1 \\
\hline mean & $4.4 \pm 0.1$ & $3.3 \pm 0.15$ \\
\hline Organic matter digested, $\mathrm{g} /$ day & 269 & 401 \\
\hline \multicolumn{3}{|l|}{ Nutritive value index, $\mathrm{KJ} / \mathrm{kg}^{0.75} / \mathrm{d}$} \\
\hline ram & 433.7 & 391.1 \\
\hline ewe & 446.2 & 368.7 \\
\hline mean & $439.9 \pm 6.3^{\mathrm{a}}$ & $379.9 \pm 11.2^{b}$ \\
\hline
\end{tabular}

${ }^{a, b}$ means within row with different superscript differ at $\mathrm{P}<0.001$

$\pm \mathrm{SD}$ 
The nutritive value of guinea grass in both seasons is presented in Table 5 . There was significant difference $(\mathrm{P}<0.001)$ in the nutritive value index $(\mathrm{NVI})$ of guinea grass in the dry and wet seasons. Daily crude protein intake (DCPI) was $3.6 \pm 0.10$ and $9.4 \pm 0.05 \mathrm{gDM} / \mathrm{kgW}^{0.75} / \mathrm{d}$ for lambs in the dry and wet seasons, respectively. The effect of season on $\mathrm{CP}$ content of the forage was observed to influence daily protein intake of the lambs. However, the high daily protein intake and organic matter digested in the wet season by the lambs were not effectively utilized for ADG. The low energy content may be implicated. Energy requirement is important to general performance of sheep and energy deficiency can impair the utilization of other nutrients.

The gross energy content of guinea grass in the wet season was comparatively low, however digestible energy (DE) and metabolizable energy intake (MEI) were similar in both wet and dry seasons. Season and sex of lambs had no significant effect in MEI $(\mathrm{P}>0.001)$ of the guinea grass, despite the differences in gross energy values of guinea grass in both seasons. Our results on MEI of lambs on guinea grass supports Kirkpatrick and Steen (1999) who observed a similar trend in lambs fed on forage alone. DE values of guinea grass for both seasons are lower than values reported by Van Man and Wiktorsson (2003) for guinea grass in Vietnam.

Our results confirm that season has effects on the chemical composition and nutritive value of native guinea grass. Wet season guinea grass (a re-growth) had more CP content and its DMI was higher than in the dry season. Based on DMI, ADG, NVI, DCPI, DE, MEI and apparent nutrient digestibility coefficients of lambs our data further confirmed that available native guinea grass would not adequately support the growth of lambs in the dry and wet seasons because of its poor nutritive quality. In conclusion, supplementation is recommended to improve liveweight gain and general performance of the Fiji Fantastic sheep on sole diet of native guinea grass in the dry and wet seasons.

\section{REFERENCES}

Adegbola T.A., Okorie A.U, Aharanwa J.C., Eruchalu M.C., 1987. Blood plasma urea and ammonia concentrations of grazing and grazing-supplemented ruminants in humid tropical environment. East Afr. Agr. Forest. J. 53, 19-22

AOAC, 1995. Official Methods of Analysis, Association of Official Analytical Chemists. $6^{\text {th }}$ Edition. Arlington, VA

Aregheore E.M., 2001. Nutritive value and utilization of three grass species by cross-bred AngloNubian goats in Samoa. Asian-Austr. J. Anim. Sci. 14, 1389-1393

Aregheore E.M., Cawa K., 2000. Voluntary intake by crossbred Anglo-Nubian goats of water hyacinth (Eichhornia crassipes) fed in two states plus guinea grass (Panicum maximum) in confinement. Scientia Agr. Bohemica 31, 261-271

Aumont G., Caudron I., Saminadin G., Xand A., 1995. Sources of variation in nutritive values of tropical forage from the Caribbean. Anim. Feed Sci. Tech. 51, 1-13 
Buxton D.R., 1996. Quality-related characteristics of forages as influenced by plant environment and agronomic factors. Anim. Feed Sci. Tech. 59, 37-49

Crampton E.W., Donefer E., Llory L.E., 1960. Nutritive value index for forage. J. Anim. Sci. 19, $538-544$

Fawcett J.K., Scott J.E., 1960. A rapid and precise method of urea determination. Brit. J. Clin. Pathol. 13, 156-159

Galyean M.L., Wagner D.G., Owens F.N., 1979. Level of feed intake and extent of digestion of high concentrate diets by steers. J. Anim. Sci. 49, 199-210

Giger-Reverdin S., Gihad E.A., 1991. Water metabolism and intake in goats. In: P. Morand-Fehr (Editor). Goat Nutrition. Pudoc, Wageningen, pp. 37-44

Gihad E.A., 1976. Studies on the nutritional value of pasture species in Zambia. East Afr. Agr. Forest. J. 41, 335-339

Gohl B., 1981. Tropical Feeds. Feed Information Summaries and Nutritive Values. Food and Agriculture Organization of the United Nations (FAO), Rome (Italy), pp. 529

Hallford D.M., Gaylean M.L., 1982. Scrum profiles in fine wool sheep. Bovine Prac. 3, 26

Kirkpatrick D.E., Steen R.W.J., 1999. Performance, carcass composition and energy retention of lambs offered two contrasting grass-based forages. J. Agr. Sci. 132, 117-126

Kunst A., Draeger B., Ziegenhorn J., 1983. UV-Methods with Hexokinase and Glucose-6-Phosphate Dehydrogenase. Methods of Enzymatic Analysis (6). Bergmeyer, HU, Verlag Chemie, Deerfield, pp. 163-172

Laredo M.A., Minson D.J., 1973. The voluntary intake, digestibility, and retention time by sheep of leal and stem fractions of five grasses. Aust. J. Agr. Res. 24, 875-888

MAFF, 1999. Ministry of Agriculture, Fisheries and Forestry, Pasture Unit, Koronivia (Fiji)

Manueli P.R., 1997. Sheep in the humid tropics - Evolution of the Fiji sheep. Fourth International Congress for Sheep Veterinarians. Australian Sheep Veterinary Society Conference Proceedings. University of New England, Armidale N.S.W. (Australia), pp. 326-330

Milford R., Minson D.J., 1966. Intake of tropical pasture species. In: Proceedings of IX International Grassland Congress 1, 815-822

Minitab for Windows, 2000. Minitab release - Version 13. Minitab Inc., 3081 Enterprise Drive, State College, PA 16801-3008, 814-223-3280 (USA)

Norton B.W., Ash A.J., 1985. Recent advances in goat nutrition in Australia. In: R.B. Cumming (Editor). Recent Advances in Animal Nutrition in Australia. Paper No. 37, The University of New England Publishing Unit, Armidale

NRC, 1985. Nutrient Requirements of Sheep. 6th revised Edition. National Academy of Sciences. Washington, DC

Phimphachanhvongsod V., Ledin I., 2002. Performance of growing goats fed Panicum maximum and leaves of Gliricidia sepium. Asian-Austr. J. Anim. Sci. 15, 1585-1590

Poppi D.P., Mclennan S.R., 1995. Protein energy utilization by ruminants at pasture. J. Anim. Sci. $73,278-290$

Ranacou E., 1986. Review of research and observations on pastures in Fiji (1920-1985). 1. Para grass (Brachiaria mutica). Fiji Agr. J. 48, 12-18

Van Mann N., Wiktorsson H., 2003. Forage yield, nutritive value, feed intake and digestibility of three grass species as affected by harvest frequency. Trop. Grasslands 37, 101-110

Van Soest P.J., Robertson J.B., Lewis B.A., 1991. Methods for dietary fiber, neutral detergent fiber and non-starch polysaccharides in relation to animal nutrition. J. Dairy Sci. 74, 3583-3597

Wright P.L., Pope A.L., Phillips P.H., 1962. Effect of protein and energy intake on lamb production and certain blood constituents of ewes. J. Anim. Sci. 21, 602-610 


\section{STRESZC7.ENIE}

Wplyw pory roku i płci na pobranie suchej masy, strawność i wyniki produkcyjne owiec Fiji Fantastic, żywionych miejscowym prosem olbrzymim (Panicum maximum)

Doświadczenie przeprowadzono $w$ dwóch porach roku w układzie czynnikowym $2 \times 2$ na 12 jagniętach (6 tryczkach i 6 jarkach) pochodzących ze stada hodowlanego. Sześć jagniąt ( 3 q i 38 ) o m.c. przed rozpoczęciem doświadczenia $25,1 \pm 1.15 \mathrm{~kg}$ i wieku $5-6$ miesięcy oraz 6 jagniąt ( 3 † i 3 3) o początkowej m.c. przed rozpoczęciem doświadczenia $20,0 \pm 0,00 \mathrm{~kg}$ i wieku $4-5$ miesięcy użyto w doświadczeniu 1 (okres suszy - D, 3.10.2002-28.01.2003; 92 dni) i 2 (okres wilgotny - W, 12.028.05.2003; 84 dni).

Skład chemiczny prosa zależał od pory roku; z wyjątkiem białka ogólnego, zawartość s.m., NDF, ADF, hemicelulozy, celulozy i energii (MJ/kg s.m.) była większa w okresie D niż W. W okresach D i W pobranie s.m. wynosiło $536 \pm 0,50$ i $792 \pm 7,51 \mathrm{~g} / \mathrm{sztuka} /$ dzień, średnie dzienne przyrosty $34,5 \pm 2.5$ and $35,5 \pm 3.5 \mathrm{~g} / \mathrm{sztuka} /$ dzień, a wykorzystanie paszy $15,6 \pm 1,1$ i $22,5 \pm 2,0 \mathrm{~kg} \mathrm{s.m.} / \mathrm{kg}$ przyrostu. Pobranie białka ogólnego wynosiło 3,6 $\pm 0,10$ i 9,4 $\pm 0,058 / \mathrm{kg} \mathrm{W}^{0.75} / \mathrm{dzień}$, odpowiednio. Ilość spożytej wody (Wl) w ciagu okresów D i W wynosiła odpowiednio $1328.8 \pm 9.9$ i 550,2 49.8 L; na WI istotny $(\mathrm{P}<0,001)$ wpływ miała pora roku i pobranie s.m.

Stężenic $\mathrm{N}$ mocznikowego i glukozy w krwi było podobne u jagniąt, niezależnie od płci, w obydwóch porach roku. Stwierdzono wpływ pory roku na pozorną strawność CP, NDF, hemicelulozy i cnergii, a także $(\mathrm{P}<0,001)$ na wskaźnik wartości pokarmowej prosa.

Otrzymane dane wskazują, że miejscowe proso olbrzymie w obydwóch badanych okresach jest niewystarczającą paszą dla rosnących jagniąt ze względu na niską wartość pokarmową i że zalecany jest dodatek innych pasz. dla poprawienia przyrostów. 